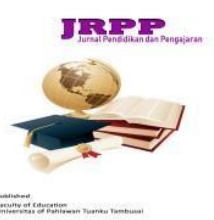

Jurnal ReviewPendidikan dan Pengajaran

http://journal.universitaspahlawan.ac.id/index.php/jrpp

Volume 2 Nomor 2, Desember 2019

P-2655-710X e-ISSN 2655-6022
Submitted : $28 / 11 / 2019$

Reviewed :05/12/2019

Accepted :08/12/2019

Published :28/12/2019
Arozatulo

Bawamenewi ${ }^{1}$

\section{PENGEMBANGAN BAHAN AJAR MEMPRAFRASEKAN PUISI "AKU" BERDASARKAN MODEL PEMBELAJARAN PROBLEM BASED LEARNING (PBL)}

\begin{abstract}
Abstrak
Pengembangan bahan ajar memparafrasekan puisi "Aku" berdasarkan Model Pembelajaran Problem Based Learning (PBL). Rancangan penelitian yang digunakan dalam penelitian adalah metode penelitian dan pengembangan atau Research and Development (R\&D). Berdasarkan hasil temuan penelitian dan hasil analisis maka penulis mengambil beberapa kesimpulan yaitu: (1). Berdarkan validasi produk ternyata modul menulis parafrase puisi "Aku"yang dikembangkan memenuhi syarat validitas artinya modul memprafrasekan puisi "Aku" yang dikembangkan dapat digunakan sebagai bahan ajar di SD Negeri No. 078467 Buhawa Hilimbowo; (2). Berdasarkan pengolahan data dari lembar observasi ternyata modul memprafrasekan puisi "Aku" yang dikembangkan memenuhi syarat praktikalitas artinya modul yang dikembangkan praktis jika digunakan sebagai bahan ajar di SD; dan (3). Berdasarkan pengolahan hasil belajar siswa ternyata modul memprafrasekan puisi "Aku" yang dikembangkan melalui syarat efektifitas, artinya modul memprafrasekan puisi "Aku" yang efektif jika digunakan sebagai bahan ajar di SD.
\end{abstract}

Kata Kunci: Bahan Ajar, Parafrase, PBL

\begin{abstract}
The development of teaching materials paraphrases the poem "Aku" based on the Problem Based Learning (PBL) Learning Model. The research design used in research is a research and development method or Research and Development $(R \& D)$. Based on the research findings and the results of the analysis the authors draw several conclusions, namely: (1). Based on product validation, it turns out that the writing module paraphrasing the poem "Aku" which was developed meets the validity requirements, meaning that the preprogramming poem " $I$ " developed can be used as teaching material in SD Negeri No. 078467 Buhawa Hilimbowo; (2). Based on the processing of data from the observation sheet it turns out that the pre-written poetry module "I" that was developed meets the practicality requirements meaning that the module is developed practically if used as teaching material in elementary schools; and (3). Based on the processing of student learning outcomes it turns out that the "Aku" poetry refreshing module was developed through effectiveness requirements, meaning that the poetry "Aku" pre-reproduction module is effective if used as teaching material in elementary schools.
\end{abstract}

Keywords: Teaching Material, Paraphrase, PBL

\footnotetext{
${ }^{1}$ Prodi Bahasa Indonesia, IKIP Gunungsitoli Alamat email: arozatulobawamenewi825@gmail.com
} 


\section{PENDAHULUAN}

Pesatnya kecanggihan teknologi terutama di lingkungan pendidikan formal, seiring merosotnya tingkat moral anak yang tanpa dipungkiri akan merusak generasi masa bangsa. Keberhasilan siswa bertitik pusat pada profesionalisme guru sebagaimana tercantum dalam Undang-undang RI nomor 20 tahun 2003 bahwa guru adalah pendidik profesional dengan tugas utama mendidik, mengajar, membimbing, mengarahkan, melatih, menilai, dan mengevaluasi peserta didik pada pendidikan anak usia dini jalur pendidikan formal, pendidikan dasar, dan pendidikan menengah (Anonim, 2003).

Pada dasarnya setiap siswa memiliki kemampuan yang berbeda-beda. Oleh karena itu seorang guru diharapkan dapat memilih dan menerapkan model dan pendekatan pembelajaran yang dapat memfasilitasi kemampuan siswanya. Dengan model dan pendekatan yang tepat diharapkan siswa dapat mengembangkan segala potensi yang dimiliki secara maksimal sesuai dengan kemampuannya masing-masing.

Manusia adalah individu yang senantiasa berhadapan dengan masalah karena ia juga berhadapan dengan lingkungan. Begitu juga dengan siswa sebagai individu senantiasa berhadapan dengan masalah lingkungan sehingga perlu dibekali ketrampilan atau kemampuan untuk memecahkan masalah. Gambaran rinci kelima langkah yaitu guru melakukan apresiasi dengan cara, guru memulai pembelajaran dengan memberikian pertanyaan kepada siswa. guru bertanya pengalaman-pengalaman penting apa yang tidak terlupakan berkaitan oleh siswa; guru memberikan waktu kepada siswa untuk mengingatkan pengalaman mereka yang tidak terlupakan berkaitan dengan materi yang ada; guru memotivasi siswa dengan cara guru menjelaskan bahwa puisi dapat dilakukan oleh siapa saja, setiap orang memiliki kreatifitas tersendiri yang harus dikembangkan.

Parafrase yang dimaksud dalam penelitian ini adalah parafrase puisi "Aku" karangan Chairil Anwar. Puisi merupakan salah satu bentuk karya sastra yang memiliki nilai keindahan. Puisi adalah karya sastra dengan bahasa yang dipadatkan, dipersingkat dan diberi irama dengan bunyi yang sama dan pemilihan kata-kata kias (imajinatif). Puisi Aku karangan Chairil Anwar adalah dua sisi yang tak pernah bisa dilepaskan serta mempunyai banyak sisi yang menarik untuk diketahui lebih dalam dalam karangan tersebut (Waluyo, 2005:1)

Model Pembelajaran Problem Based Learning adalah merupakan suatu model pengajaran dengan pendekatan pembelajaran siswa pada masalah autentik. Masalah autentik dapat diartikan sebagai suatu masalah yang sering ditemukan siswa dalam kehidupan sehari-hari. Dengan PBL siswa dilatih menyusun sendiri pengetahuannya, mengembangkan keterampilan pemecahan masalah, mandiri serta meningkatkan kepercayaan diri.

\section{A. Konsep Dasar Bahan Ajar}

\section{Pengertian Bahan Ajar}

Materi ajar adalah seperangkat materi yang disusun secara sistematis sehingga tercipta lingkungan atau suasana yang memungkinkan siswa untuk belajar (Prastowo, 
2014). Selanjutnya, pengertian materi ajar yaitu (a) materi ajar merupakan informasi, alat dan teks yang diperlukan guru atau instruktur untuk perencanaan dan penelaahan implementasi pembelajaran, (b) materi ajar adalah segala bentuk bahan yang digunakan untuk membantu guru atau instruktur dalam melaksanakan kegiatan belajar mengajar di kelas. Bahan yang dimaksud bisa berupa bahan tertulis maupun bahan tidak tertulis, (c) materi ajar adalah seperangkat materi yang disusun secara sistematis baik tertulis maupun tidak sehingga tercipta lingkungan atau suasana yang memungkinkan siswa untuk belajar. Bahan ajar pada dasarnya merupakan segala bahan (baik informasi, alat, maupun teks) yang disusun secara sistematis, yang menampilkan sosok utuh dari kompetensi yang akan dikuasai siswa dan digunakan dalam proses pembelajaran dengan tujuan perencanaan dan penelaahan implementasi pembelajaran (Prastowo, 2012)

Selain itu, bahan ajar merupakan segala bentuk bahan yang digunakan untuk membantu guru atau instruktor dalam melaksanakan kegiatan belajar mengajar. Bahan yang dimaksud bisa berupa bahan tertulis maupun bahan tidak tertulis. Dari beberapa pendapat di atas, dapat disimpulkan bahwa materi ajar adalah suatu pembelajaran yang disusun oleh guru dalam membantu peserta didik dalam kegiatan pembelajaran di sekolah (Abied, 2009).

\section{Tujuan dan Manfaat Penyusunan Bahan Ajar}

Tujuan bahan ajar adalah menyediakan bahan ajar yang sesuai dengan tuntutan kurikulum dengan mempertimbangkan kebutuhan siswa, yakni bahan ajar yang sesuai dengan karakteristik dan setting atau lingkungan sosial siswa, membantu siswa dalam memperoleh alternatif bahan ajar di samping buku buku teks yang terkadang sulit diperoleh, memudahkan guru dalam melaksanakan pembelajaran. Sedangkan manfaat adalah diperoleh bahan ajar yang sesuai tuntutan kurikulum dan sesuai dengan kebutuhan belajar siswa, tidak lagi tergantung kepada buku teks yang terkadang sulit untuk diperoleh, bahan ajar menjadi labih kaya karena dikembangkan dengan menggunakan berbagai referensi.

\section{Prinsip dalam Memilih Bahan Ajar}

Setiap kegiatan pembelajaran yang harus dicapai memiliki prinsip yang dilakukan begitu juga dalam hal pemilihan bahan ajar. Sudrajat (2008) mengatakan bahwa prinsip dalam memilih materi ajar di antaranya:

a) Prinsip relevansi artinya materi pembelajaran hendaknya relevan memiliki keterkaitan dengan pencapaian standar kompetensi dan kompetensi dasar.

b) Prinsip konsistensi artinya antara bahan ajar dengan Kompetensi Dasar yang harus dikuasai siswa. Misalnya, Kompetensi Dasar yang harus dikuasai siswa

c) Prinsip kecukupan artinya materi yang diajarkan hendaknya cukup memadai dalam membantu siswa menguasai Kompetensi Dasar yang diajarkan. Materi tidak boleh terlalu sedikit, dan tidak boleh terlalu banyak. Jika terlalu sedikit akan kurang membantu mencapai Standar Kompetensi dan Kompetensi Dasar. Sebaliknya, jika terlalu banyak akan membuang-buang waktu dan tenaga yang tidak perlu untuk mempelajarinya. 


\section{Langkah-langkah Pemilihan Materi Ajar}

Ada beberapa langkah-langkah pemilihan materi ajar adalah:

a) Mengidentifikasi aspek-aspek yang terdapat dalam Standar Kompetensi dan Kompetensi Dasar. Sebelum menentukan materi pembelajaran terlebih dahulu perlu diidentifikasi aspek-aspek Standar Kompetensi dan kompetensi dasar yang harus dipelajari atau dikuasai siswa. Aspek tersebut perlu ditentukan, karena setiap aspek Standar Kompetensi dan Kompetensi Dasar memerlukan jenis materi yang berbedabeda dalam kegiatan pembelajaran.

b) Identifikasi jenis-jenis materi pembelajaran. Sejalan dengan berbagai jenis aspek Standar Kompetensi, materi pembelajaran juga dapat dibedakan menjadi jenis materi aspek kognitif, afektif, dan psikomotorik. Materi pembelajaran aspek kognitif secara terperinci dapat dibagi menjadi empat jenis, yaitu fakta, konsep, prinsip dan prosedur. Materi jenis fakta adalah materi berupa nama-nama objek, nama tempat, nama orang, lambang, peristiwa sejarah, nama bagian atau komponen suatu benda, dan lain sebagainya. Materi konsep berupa pengertian, definisi, hakekat, inti isi. Materi jenis prinsip berupa dalil, rumus, postulat, paradigma, teorema. Materi jenis prosedur berupa langkah-langkah mengerjakan sesuatu secara urut, misalnya langkahlangkah menelpon, cara-cara pembuatan telur asin atau cara-cara pembuatan bel listrik. Materi pembelajaran aspek afektif meliputi: pemberian respon, penerimaan (apresisasi), internalisasi, dan penilaian. Materi pembelajaran aspek motorik terdiri dari gerakan awal, semi rutin, dan rutin.

c) Memilih jenis materi yang sesuai dengan standar kompetensi dan kompetensi dasar. Materi yang akan diajarkan perlu diidentifikasi apakah termasuk jenis fakta, konsep, prinsip, prosedur, afektif, atau gabungan lebih daripada satu jenis materi. Dengan mengidentifikasi jenis-jenis materi yang akan diajarkan, maka guru akan mendapatkan kemudahan dalam cara mengajarkannya. Setelah jenis materi pembelajaran teridentifikasi, langkah berikutnya adalah memilih jenis materi tersebut yang sesuai dengan standar kompetensi atau kompetensi dasar yang harus dikuasai siswa. Identifikasi jenis materi pembelajaran juga penting untuk keperluan mengajarkannya. Sebab, setiap jenis materi pembelajaran memerlukan strategi pembelajaran atau metode, media, dan sistem evaluasi atau penilaian yang berbeda- beda.

d) Memilih sumber bahan ajar. Setelah jenis materi ditentukan langkah berikutnya adalah menentukan sumber bahan ajar. Materi pembelajaran atau bahan ajar dapat kita temukan dari berbagai sumber seperti buku pelajaran, majalah, jurnal, koran, internet, media audiovisual.

\section{B. Konsep Dasar Parafrase Puisi}

\section{Pengertian Parafrase Puisi}

Kridalaksana (2008) mengatakan bahwa parafrase artinya mengungkapkan kembali dengan bahasa dan kalimat sendiri secara tertulis berdasarkan teks yang telah dibaca. Selanjutnya, Depdiknas (2012) mengatakan bahwa prafrase artinya penguraian 
kembali sebuah teks dalam bentuk yang lain, dengan maksud untuk dapat menjelaskan makna yang tersembunyi. Selain itu, Malik, dkk (2006) mengemukakan beberap definisi parafrase yaitu:

a) Pengungkapan kembali suatu tuturan dari sebuah tingkatan atau macam bahasa menjadi macam yang lain tanpa mengubah pengertiannya.

b) Penguraian kembali sebuah teks dalam bentuk yang lain, dengan maksud untuk dapat menjelaskan makna yang tersembunyi.

c) Pengungkapan kembali suatu tuturan atau karangan menjadi bentuk lain namun tidak mengubah pengertian awal.

Dari pendapat di atas, dapat disimpulkan bahwa yang dimaksud parafrase adalah mengubah puisi menjadi bentuk sastra lain (prosa). Hal itu berarti bahwa puisi yang tunduk pada aturan-aturan puisi diubah menjadi prosa yang tunduk pada aturan-aturan prosa tanpa mengubah isi puisi tersebut. Perlu diketahui bahwa parafrase merupakan metode memahami puisi, bukan metode membuat karya sastra. Dengan demikian, memparafrasekan puisi tetap dalam kerangka upaya memahami puisi.

\section{Cara Membuat Parafrase}

Kridalaksana (2008) mengatakan bahwa ada beberapa hal yang perlu dilakukan untuk membuat parafrase dari sebuah bacaan yaitu:

a) Bacalah naskah yang akan diparafrasakan sampai selesai untuk memperoleh gambaran umum isi bacaan atau tulisan.

b) Bacalah naskah sekali lagi dengan memberi tanda pada bagian-bagian penting dan kata-kata kunci yang terdapat pada bacaan.

c) Catatlah kalimat inti dan kata-kata kunci secara berurut.

d) Kembangkan kalimat inti dan kata-kata kunci menjadi gagasan pokok yang sesuai dengan topik bacaan.

e) Uraikan kembali gagasan pokok menjadi paragraf yang singkat dengan bahasa sendiri.

\section{Pengertian Puisi}

Secara etimologis istilah puisi berasal dari kata bahasa Yunani poites, yang berarti pembangun, pembentuk, pembuat dalam bahasa Latin dari kata poeta, yang artinya membangun, menyebabkan, menimbulkan, menyair dalam perkembangan selanjutnya, makna kata tersebut menyempit menjadi hasil seni sastra yang kata-katanya disusun menurut syarat tertentu dengan menggunakan irama, sajak dan kadang-kadang kata kiasan.

Waluyo (2005:1) mengatakan bahwa puisi adalah karya sastra dengan bahasa yang dipadatkan, dipersingkat dan diberi irama dengan bunyi yang sama dan pemilihan katakata kias (imajinatif). Selanjutnya Altenbernd dalam Pradopo (2012) mengatakan bahwa puisi adalah pendramaan pengalaman yang bersifat penafsiran (menafsirkan) dalam bahasa berirama. Selain itu, Tarigan (2009) mengatakan bahwa puisi adalah hasil penyulingan pengalaman yang tertangkap pikiran dan perasaan dari suatu objek dan intensifikasi serupa itu memerlukan pola struktur kata yang lebih tinggi dari pada prosa. 


\section{Puisi Chairil Anwar}

Waluyo (2005) mengatakan bahwa Chairil Anwar adalah penyair terbesar angkatan 45. Majalah Tempo tahun 2000 menyebut Chairil Anwar sebagai salah seorang dari 10 orang besar di Indonesia sepanjang abad XX (1901-1999). Bahasa yang diciptakan Chairil Anwar merupakan bahasa yang bebas dari pola bahasa Melayu. Ia menciptakan bahasa yang demokratis sebagai contoh ia tidak mengatakan beta tetapi ia menyebut dirinya aku. Kumpulan puisi Chairil Anwar berjuduk Kerikil Tajam (1946), Deru Campur Debu (1949), Tiga Menguak Takdir (1950).

Selanjutnya, Chairil Anwar adalah seorang penyair yang menuliskan apa saja yang ditemukannya dan dihadapinya dalam pencarian itu, sebagaimana perkataan Sastrowardoyo dalam Ginting (2007) bahwa pengarang seperti Chairil Anwar, Sitor Situmorang, Ajip Rosidi, dan Goenawan Mohammad terombang-ambing di antara dua kutub, kebudayaan daerah dan kota, tradisi dan modern, Timur dan Barat. Lebih lanjut lagi, dikatakan bahwa nasib manusia perbatasan adalah buah dari pencarian hendak modern itu. Jadi, puisi "Aku" ini adalah buah hasil dari pencarian Chairil Anwar sebagai manusia perbatasan yang terombang-ambing di antara dua kutub sebagaimana yang dikatakan oleh Sastrowardoyo. Puisi "Aku" dan Chairil Anwar adalah dua sisi yang tak pernah bisa dilepaskan. Sebagaimana pengarangnya, puisi "Aku" ini juga mempunyai banyak sisi yang menarik untuk diketahui lebih dalam.

Selain itu, puisi "Aku" ini adalah puisi Chairil Anwar yang paling memiliki corak khas dari beberapa sajak lainnya. Alasannya, sajak Aku bersifat destruktif terhadap corak bahasa ucap yang biasa digunakan penyair Pujangga Baru seperti Amir Hamzah sekalipun, idiom binatang jalang yang digunakan dalam sajak tersebut pun sungguh suatu pendobrakan akan tradisi bahasa ucap Pujangga Baru.

Puisi "Aku" karangan: Chairil Anwar

AKU

Kalau sampai waktuku

Ku mau tak seorang kan merayu

Tidak juga kau

Tak perlu sedu sedan itu

Aku ini binatang jalang

Dari kumpulannya terbuang

Biar peluru menembus kulitku

Aku tetap meradang menerjang

Luka dan bisa kubawa berlari

Berlari

Hingga hilang pedih peri

Dan aku akan lebih tidak perduli

Aku mau hidup seribu tahun lagi

(Kerikil Tajam, 1946) 


\section{Konsep Dasar Modul}

\section{Pengertian Modul}

Sukarto (2009) mengatakan bahwa modul adalah materi pelajaran yang disusun dan disajikan secara tertulis sedemikian rupa sehingga pembacanya diharapkan dapat menyerap sendiri materi tersebut, dengan demikian modul adalah buku yang dirancang sebagi bahan pembelajaran mandiri siswa. Selanjutnya, Suryosubroto (2009) mengatakan bahwa modul adalah unit program belajar mengajar terkecil yang secara terperinci menggariskan tujuan instruksional umum yang dicapai, topik yang akan dijadikan pangkal proses belajar mengajar, peranan guru dalam proses belajar mengajar, dan program evaluasi yang akan dilaksanakan.

Dari pendapat di atas, dapat disimpulkan bahwa modul adalah materi yang yang disusun secara sistematis dan logi sehingga dapat membantu siswa dalam belajar.

\section{Tujuan dan Manfaat Penyusunan Modul}

Tujuan penyusunan modul salah satunya adalah untuk menyediakan bahan ajar yang sesuai dengan tuntutan kurikulum dengan mempertimbangkan kebutuhan peserta didik, yakni bahan ajar yang sesuai dengan karakteristik materi ajar dan karakteristik peserta didik serta setting atau latar belakang lingkungan sosialnya. Selain itu, modul memiliki berbagai manfaat baik ditinjau dari kepentingan peserta didik maupun dari kepentingan guru yaitu:

a) Bagi peserta didik modul bermanfaat antara lain peserta didik memiliki kesempatan melatih diri belajar secara mandiri, belajar menjadi lebih menarik karena dapat dipelajari di luar kelas dan di luar jam pembelajaran, berkesempatan mengekspresikan cara-cara belajar yang sesuai dengan kemampuan dan minatnya, berkesempatan menguji kemampuan diri sendiri dengan mengerjakan latihan yang disajikan dalam modul, mampu membelajarkan diri sendiri, mengembangkan kemampuan peserta didik dalam berinteraksi langsung dengan lingkungan dan sumber belajar lainnya

b) Bagi guru, penyusunan modul bermanfaat karena dapat mengurangi ketergantungan terhadap ketersediaan buku teks, memperluas wawasan karena disusun dengan menggunakan berbagai referensi, menambah khasanah pengetahuan dan pengalaman dalam menulis bahan ajar, membangun komunikasi yang efektif antara dirinya dengan peserta didik karena pembelajaran tidak harus berjalan secara tatap muka, menambah angka kredit jika dikumpulkan menjadi buku dan diterbitkan.

\section{Keuntungan Penggunaan Modul Bagi Siswa dan Guru}

Keuntungan penggunaan modul bagi siswa adalah: (a). Adanya balikan artinya balikan yang disampaikan oleh siswa lebih cepat sehingga mengetahui taraf hasil belajarnya; (b). Penguasaan tuntas artinya setiap siswa mendapat kesempatan untuk mencapai angka tinggi dengan mengusai bahan pelajaran secara tuntas; (c). Motivasi artinya pengajaran yang baik dan dapat diterima oleh siswa maka guru memberikan motivasi dalam kegiatan pembelajaran di kelas; (d). Adanya kerjasama artinya siswa dalam proses belajar mengajar adanya kerjasama antara satu dengan yang lain sehingga 
dapat membantu siswa yang kurang memahami pembelajaran; dan (e). adanya pengajaran remedial.

Sedangkan bagi guru memiliki keuntungan yaitu: (1). Dapat meningkatkan profesi seorang guru artinya dapat menimbulkan pertanyaan-pertanyaan mengenai proses belajar itu sendiri; (2). Rasa kepuasan artinya modul disusun dengan cermat sehingga mempermudah bagi siswa dalam belajar sesuai dengan metode yang digunakan; (3). Kebebasan rutin artinya guru dibebaskan dari persiapan karena telah tercantum seluruhnya materi pada modul; (4). Mencegah kemubajiran artinya dapat berdiri sendiri mengenai topik tertentu dan dapat digunakan dalam berbagai mata pelajaran; (5). Pengayaan artinya guru mendapat waktu lebih banyak untuk memberikan penjelasan kepada siswa sesuai materi yang akan dibahas.

\section{Ciri-ciri Modul}

Ciri sebuah modul adalah didahului oleh pertanyaan sasaran belajar, pengetahuan siswa disusun sedemikian rupa, memuat sistem penilaian berdasarkan penguasaan, memuat semua unsur bahan pelajaran, memberi peluang bagi perbedaan antara individu peserta didik, mengarah pada suatu tujuan tuntas.

\section{Unsur-unsur Modul}

Ada beberapa unsur-unsur dalam sebuah modul, (Suryosubroto, 2009) yaitu: (1). Pedoman guru. Pedoman guru berisi petunjuk-petunjuk guru agar pengajaran dapat diselenggarakan secara efesien, juga memberi penjelasan tentang: (a). Macam-macam kegiatan yang dilakukan oleh kelas; (b). Waktu yang disediakan untuk menyelesaikan modul tersebut; (c). Alat-alat pelajaran yang harus digunakan; dan (d). Petunjuk- petunjuk evaluasi; (2). Lembar kegiatan siswa. Lembar kegiatan ini memuat materi pelajaran yang harus dikuasai oleh siswa. Penyusunan materi pelajaran disesuaikan dengan tujuantujuan instruksional yang akan dicapai yang telah dirumuskan dalam modul tersebut. Materi pelajaran juga disusun secara teratur langkah demi langkah sehingga dapat diikuti dengan mudah oleh siswa; dan (3). Lembar kerja. Lembar kerja ini menyertai lembar kegiatan siswa digunakan untuk menjawab atau mengerjakan soal- soal atau masalah-masalah yang harus dipercahkan. Lembar kegiatan siswa itu sendiri harus dijaga supaya tetap bersih tidak boleh ada coretan apapun didalamnya, sebab buku modul ini akan digunakan lagi untuk siswa-siswa yang lain pada tahun-tahun berikutnya.

Jadi setelah siswa mempelajari lembar kegiatan mereka harus bekerja atau melaksanakan kegiatan-kegiatannya pada lembar kerja ini.

a) Kunci lembar kerja maksudnya diberikan kunci lembar kerja ialah agar siswa dapat mengevaluasi (mengoreksi) sendiri hasil pekerjaanya. Apabila siswa membuat kesalahan-kesalahan dalam pekerjaannya maka ia dapat meninjau kembali pekerjaannya.

b) Lembaran Tes. Tiap modul disertai lembar tes, yakni alat evaluasi yang digunakan sebagai pengukur keberhasilan atau tercapai tidaknya tujuan yang telah dirumuskan dalam modul itu. Jadi keberhasilan pengajaran dengan sesuatu mdoul tidak dinilai 
atas dasar jawaban-jawaban pada lembar kerja. Jadi lembaran tes berisi soal-soal untuk menilai keberhasilan murid dalam mempelajari bahan yang disajikan dalam modul tersebut.

c) Kunci lembaran tes. Tes ini disusun oleh penulis modul yang bersangkutan, sehingga kunci tes inipun juga dibuat oleh penulis modul. Gunanya sebagai alat koreksi sendiri terhadap penilain yang dilaksanakan.

Berdasarkan identifikasi masalah di atas, maka peneliti memilih model pembelajaran Problem Based Learning (PBL) karena banyak memberikan keuntungan bagi siswa antara lain memberikan arah dalam mengembangkan dalam pengukuran atau penilaian, membantu anak didik dalam proses belajar mengajar dan membantu siswa untuk mandiri. Selain alasan di atas, peneliti memilih model pembelajaran Problem Based Learning $(P B L)$, peneliti merasa lebih mudah menggunakan model tersebut karena peneltian ini lebih menggutamakan pada tahap produk yang akan dihasilkan

\section{METODE}

Penelitian ini dilaksanakan SD Negeri No. 078467 Buhawa Hilimbowo yang terletak di Jalan Desa Buhawa Kecamatan Idanotae Kabupaten Nias Selatan, Sumatera Utara. Model pengembangan modul merupakan seperangkat kegiatan yang dilakukan secara terperinci untuk mengembangkan sistem pembelajaran modul, dalam pengembangan modul diperlukan prosedur tertentu yang sesuai dengan sasaran yang ingin dicapai, susunan isi pembelajaran yang tepat, dan memenuhi kriteria yang berlaku bagi pengembangan pembelajaran. Rancangan penelitian yang digunakan dalam penelitian adalah metode penelitian dan pengembangan atau Research and Development (R\&D). Secara keseluruhan penelitian ini dilakukan selama satu tahap dalam satu semester.

Dalam penelitian ini, produk yang dihasilkan adalah modul. Langkah-langkah pengembangan yang digunakan penelitian dalam membuat modul ini terdiri dari tiga tahap pendefenisian, perancangan dan pengembangan.

1. Tahap pendefinisian. Tahap ini bertujuan untuk menetapkan dan mendefinisikan syarat-syarat pembelajaran yang mencangkup tujuan dan pembatasan materi pelajaran. Tahap ini meliputi beberapa langkah yaitu:

a) Analisis ujung depan bertujuan untuk memunculkan dan menetapkan masalah dasar yang dihadapinya dalam pengembagan bahan pengajaran dan beberapa hal yang dipertimbangkan dalam analisis ujung depan adalah kurikulum SD, teori belajar dan tantangan dan tuntutan masa depan.

b) Analisis siswa. Tujuan analisis ini adalah untuk mengetahui karakteristik meliputi latar belakang pengetahuan dan pengembangan kognitif siswa sebagai acuan dalam perancangan dan pengembangan bahan pengajaran.

c) Analisis tugas bertujuan untuk menentukan isi satuan pengajaran. Analisis tugas merupakan kumpulan prosedur untuk menentukan isi rencana pembelajaran yang dilakukan dengan merinci isi materi ajar dalam bentuk garis-garis besar yang mencangkup pemahaman tugas dalam pengajaran. Analisis tugas ini 
mencangkup analisis struktur isi, analisis prosedural dan analisis informasi, analisis konsep dan perumusan tujuan.

2. Tahap perancangan bertujuan untuk merancang serangkaian kegiatan dan perangkat pembelajaran untuk kegiatan pembelajaran dengan penerapan strategi belajar modul. Langkah-langkah pada tahap ini meliputi penyusunan tes, pemilihan media, dan desain awal perangkat.

3. Tahap pengembangan bertujuan untuk mengembangan dan menyempurnakan portotipe perangkat pembelajaran dari kegiatan desain awal. Tahap ini juga bertujuan untuk menghasilkan perangkat pembelajaran yang telah direvisi berdasarkan masukan dari validator. Kegiatan pada tahap ini meliputi validasi pacar dan revisi, uji coba I dan revisi II, uji coba II dan revisi III. Langkah selanjutnya adalah uji coba lebih lanjut dengan jumlah siswa yang sesuai dengan kelas sesungguhnya.

\section{HASIL DAN PEMBAHASAN}

\section{Penerapan Disain Model Pengembangan Model Pembelajaran PBL}

Pengembangan perangkat pembelajaran adalah serangkaian proses atau kegiatan yang dilakukan untuk menghasilkan suatu perangkat pembelajaran berdasarkan teori pengembangan yang telah ada. Sebagai seorang tenaga pengajar (guru), aktivitas kegiatannya tidak dapat dilepaskan dengan proses pengajaran. Sementara proses pengajaran merupakan suatu proses yang sistematis, yang tiap komponennya sangat menentukan keberhasilan belajar anak didik.

Salah satu model pengembangan yang digunakan dalam mengembangkan sistem dan disain ini adalah model pembelajaran PBL. Pemilihan model ini dilandasi oleh pertimbangan bahwa model ini adalah model yang paling cocok untuk pengajaran menulis, karena kepraktisan dan kelengkapannya. Selain itu, model ini lebih jelas langkahlangkahnya sehingga mudah diikuti. Agar lebih jelas bagaimana langkah- langkahnya pengembangan sistem dan disain ini, berikut disajikan secara utuh penerapan model pembelajaran PBL dalam memprafrasekan puisi "Aku".

\section{Menentukan Tujuan Kurikulum Tingkat Satuan Pendidikan (KTSP)}

Langkah pertama dalam pengembangan sistem pengajaran memprafrasekan puisi "Aku"ini adalah menentukan tujuan Kurikulum Tingkat Satuan Pendidikan (KTSP) memprafrasekan puisi "Aku" yang akan digunakan sebagai titik awal proses pengajaran.

Tujuan Kurikulum Tingkat Satuan Pendidikan (KTSP) dari pengajaran memprafrasekan puisi "Aku" ini adalah sebagai berikut ini:

a. Siswa memiliki pengetahuan dasar tentang memprafrasekan puisi "Aku".

b. Siswa dapat memahami cara membuat memprafrasekan.

c. Siswa memahami pengertian prafrase.

Ketiga tujuan yang dikemukakan di atas merupakan tujuan-tujuan yang masih bersifat umum sehingga dalam realisasinya masih perlu dijabarkan lagi dalam tujuantujuan yang lebih khusus. Penjabaran ke dalam tujuan khusus itu dilakukan setelah 
dilaksanakannya analisis pengajaran dan identifikasi kemampuan awal dan karakteristik siswa dalam memprafrasekan puisi "Aku".

Dalam Kurikulum Tingkat Satuan Pendidikan (KTSP) mata pelajaran bahasa Indonesia selalu terdapat pada tingkat SD Negeri No. 078467 Buhawa Hilimbowo Sampai pada tingkat perguruan tinggi, Standar Kompetensi yang terdapat dalam desain pembelajaran ini adalah berkomunikasi dengan bahasa Indonesia setara tingkat Madia dan Kompetensi Dasarnya adalah membuat parafrase lisan dalam konteks bekerja

\section{Analisis Pengajaran Memprafrasekan Puisi "Aku"}

Analisis pengajaran memprafrasekan puisi ini, apabila diterapkan terhadap ketiga tujuan di atas, merupakan suatu langkah atau prosedur yang menghasilkan identifikasi kemampuan-kemampuan bawahan yang diperlukan siswa dalam mencapai tujuan tersebut. Selain itu, dengan cara menganalisis pengajaran memprafrasekan puisi ini, kita akan dapat mengidentifikasikan tugas-tugas pokok yang harus dilaksanakan oleh siswa. Berdasarkan ketiga tujuan yang telah ditentukan di atas (butir 2 A, B, dan C), dapat ditentukan suatu urutan bahwa tujuan A merupakan puncak tujuan pengajaran dalam kegiatan memprafrasekan puisi "Aku", sedangkan tujuan B dan C merupakan tujuan umum yang menunjang terwujudnya tujuan umum A itu. Dengan kata lain dapat dijelaskan bahwa tujuan umum pengajaran A akan dapat dicapai apabila siswa telah menguasai tujuan umum pengajaran $B$ dan $C$. Tujuan umum pengajaran $C$, yaitu kemampuan melakukan kegiatan memprafrasekan puisi “Aku” secara tepat sesuai dengan aturan yang berlaku, tidak akan dapat terwujud apabila para siswa tidak memiliki pengetahuan dasar memprafrasekan puisi.

\section{Identifikasi Kemampuan Awal dan Karakteristik Siswa}

Pada butir 2 di depan telah disinggung istilah kemampuan awal. Yang dimaksud dengan kemampuan awal ini adalah pengetahuan atau keterampilan yang harus dimiliki oleh para siswa sebelum melakukan suatu kegiatan tertentu. Atau, secara lebih singkat dapat dikatakan sebagai bekal permulaan yang harus dimiliki oleh siswa sebelum mempelajari suatu materi tertentu. Jadi kemampuan awal ini merupakan suatu prasyarat yang harus dipenuhi sebelum mempelajari bahan yang lebih tinggi tingkat kesulitannya.

Sehubungan dengan uraian di atas, tentunya dalam mempelajari parafrase ini juga diperlukan adanya kemampuan awal yang harus dimiliki oleh siswa, yaitu kemampuan awal yang berupa pengetahuan dan keterampilan yang relevan dengan tujuan umum pengajaran mempelajari parafrase puisi seperti yang telah dirumuskan pada butir 2. Kemampuan awal ini sebenarnya telah divisualisasikan secara jelas dalam bagan 2 di depan. Dari bagan tersebut dapat diketahui bahwa kemampuan awal yang harus dimiliki oleh parasiswa dalam mencapai tujuan umum pengajaran (TUP A, B, C) adalah sebagai berikut:

1) Kemampuan memahami bahan bacaan.

Kemampuan ini merupakan kemampuan awal yang harus dimiliki oleh para siswa dalam memprafrasekan puisi. 
Kemampuan tersebut berkaitan dengan pengetahuan tentang cara dan keterampilan menggunakan pengetahuan itu untuk menulis secara efektif. Kemampuan ini merupakan kemampuan yang dimiliki siswa untuk memahami setiap makna dalam tulisan sekaligus sebagai kemampuan awal bagi pengajaran memprafrasekan puisi.

\section{2) Kemampuan memahami dan menggunakan langkah-langkah memprafrasekan puisi.}

Kemampuan ini merupakan kemampuan yang berkaitan dengan cara bagaimana seseorang itu menggunakan atau menerapkan kemampuan memprafrasekan puisi. Parafrase artinya mengungkapkan kembali dengan bahasa dan kalimat sendiri secara tertulis berdasarkan teks yang telah dibaca.

Pengetahuan tentang kemampuan awal dan karakteritik siswa sangat penting dalam pengajaran menulis di kelas. Hal ini berguna untuk mengidentifikasi bahan-bahan yang akan disampaikan kepada para siswa maupun berguna untuk menentukan strategi yang akan digunakan dalam kegiatan belajar mengajar di kelas. Untuk menentukan kemampuan awal dan karakteristik siswa ini memang tidak mudah. Namun, sementara ini ada beberapa cara untuk menentukan kemampuan tersebut, yakni dengan menggunakan tes awal yaitu tes secara formatif dan tes kemampuan siswa (Zagoto, \& Nevi, 2019)

\section{Penyusunan Tes Pengukur Keberhasilan}

Berdasarkan rumusan khusus di atas, disusun butir-butir soal tes untuk mengukur keberhasilan siswa dalam mempelajari pokok bahasan parafrase puisi "Aku" ini. Kriteria, bentuk, dan macam tes disesuaikan dengan rumusan-rumusan tujuan itu. Kriteria tes menggunakan acuan patokan yang disesuaikan dengan program, meliputi baik ranah kemampuan intelek maupun psikomotor. Bentuk tes baik subjektif maupun objektif merupakan bentuk tes yang cocok untuk rumusan-rumusan tujuan yang harus dicapai (Zagoto, dkk.,2018 Sarumaha, 2018; Dakhi, O., 2013).

\section{Pengembangan Strategi Pengajaran}

Bagian ini menyajikan atau membahas rencana pengembangan strategi yang berkaitan dengan pengajaran memprafrasekan puisi "Aku". Strategi yang digunakan untuk mencapai tujuan pengajaran memprafrasekan puisi "Aku" ini adalah strategi dengan pendekatan sistem modul. Dengan pendekatan ini diharapkan peserta didik mampu belajar secara mandiri, tanpa memerlukan kehadiran secara penuh kehadiran dan bantuan secara terus menerus dari guru. Dalam hal ini guru hanya berfungsi sebagai fasilitator saja, yang diperlukan bila peserta didik benar-benar menghadapi konsep yang sulit yang kemungkinannya tidak dapat dipecahkan berdasarkan modul itu. Selama dengan modul itu peserta didik masih dapat memecahkan persoalannya, maka guru tidak perlu mencampuri dan membahas lebih dalam kepada siswa.

Dengan sistem modul ini bukan berarti kehadiran guru sama sekali tidak diperlukan, tetapi kehadiran tersebut masih juga diperlukan yakni pada tahap-tahap awal sebelum peserta didik mulai mempelajari modul tersebut. Pada tahap-tahap awal 
yakni sebelum kegiatan pengajaran dimulai kehadiran guru memang perlu. Dalam kehadiran ini guru bahasa Indonesia akan berfungsi sebagai motivator kepada siswa untuk belajar terhadap tujuan yang seharusnya dicapai oleh peserta didik dan tingkah laku awal yang seharusnya dipersiapkan oleh siswa. Adapun dalam kegiatan berikutnya, guru hanya sebagai fasilitator saja tidak perlu menjelaskan secara mendetail kepada peserta didik.

Dalam kegiatan ini, peserta didik diberikan kesempatan untuk belajar mandiri, mencoba merangkum hasil belajarnya, mencoba menguji kemampuannya sendiri, dan menentukan langkah terhadap kemampuannya itu.

\section{SIMPULAN}

Berdasarkan hasil temuan penelitian dan hasil analisis pada bab sebelumnya, dengan memperhatikan rumusan masalah dan tujuan penelitian maka penulis mengambil beberapa kesimpulan yaitu: (1). Berdarkan validasi produk ternyata modul menulis parafrase puisi "Aku"yang dikembangkan memenuhi syarat validitas artinya modul memprafrasekan puisi "Aku" yang dikembangkan dapat digunakan sebagai bahan ajar di SD Negeri No. 078467 Buhawa Hilimbowo; (2). Berdasarkan pengolahan data dari lembar observasi ternyata modul memprafrasekan puisi "Aku" yang dikembangkan memenuhi syarat praktikalitas artinya modul yang dikembangkan praktis jika digunakan sebagai bahan ajar di SD; dan (3). Berdasarkan pengolahan hasil belajar siswa ternyata modul memprafrasekan puisi "Aku" yang dikembangkan melalui syarat efektifitas, artinya modul memprafrasekan puisi "Aku" yang efektif jika digunakan sebagai bahan ajar di SD.

\section{Saran}

Saran-saran yang dapat diberikan oleh peneliti berdasarkan temuan penelitian adalah: (1). Disarankan kepada seluruh SD Negeri No. 078467 Buhawa Hilimbowo untuk menggunakan modul memprafrasekan puisi "Aku" yang dihasilkan sebagai produk dari peneliti ini karena modul memprafrasekan puisi "Aku" telah divalisi dan diujicobakan dengan hasil valid, praktis, dan efektif; (2). Disarankan kepada guru bahasa Indonesia di SD untuk membuat modul sesuai dengan materi yang disajikan agar hasil belajar siswa pada mata pelajaran bahasa Indonesia dapat meningkat; dan (3). Disarankan kepada rekanrekan mahasiswa dan mahasiswa untuk melakukan penelitian pengembangkan pada materi yang berbeda sehingga dapat dihasilkan modu-modul yang berkualitas.

\section{DAFTAR PUSTAKA}

Anonim. 2003. Undang-Undang RI Nomor 20 Tahun 2003. Tentang Sistem Pendidikan Nasional. Bandung: Citra Utama.

Abied, 2009. Bahan Ajar dan Pengembangan Bahan Ajar, (online), (http://meetabied.wordpress.com, diakses pada 22 November 2019).

Dakhi, O. "Aplikasi Pendeteksian Kerusakan File Akibat Virus Dengan Menggunakan Metode Heuristic.” Pelita Informatika Budi Darma, vol. 4, no. 1, pp. 35-41, 2013.

Dakhi, O. 2013. Belajar Javascript Dengan Mudah Dan Detail. Jakarta: Dapur Buku. pp. 1-202. Sudrajat, Akhmad. 2008. Pengertian Pendekatan, Strategi, Metode, Teknik dan Model Pembelajaran. Bandung : Sinar Baru Algensindo.

Prastowo, Andi. 2012. Panduan Kreatif Membuat Bahan Ajar Inovatif. Yogyakarta: Diva Press. Prastowo, Andi. 2014. Panduan Kreatif Membuat Bahan Ajar Inovatif. Yogyakarta: Diva Press. 
Departemen Pendidikan Nasional. 2012. Kamus Besar Bahasa Indonesia Pusat Bahasa Edisi Keempat. Jakarta: PT. Gramedia Pustaka Utama.

Waluyo, J, Herman. 2005. Apresiasi Puisi Cetakan ketiga. Jakarta. Gramedia Pustaka Utama. Kridalaksana, Harimurti. 2008. Kamus Linguistik. Jakarta: Gramedia Pustaka Utama.

Malik, A., Isnaini, C., dan Leo. 2006. Kemahiran Menulis. Pekanbaru: UNRI Press,

Pradopo, Rachmat Djoko. 2012. Beberapa Teori Sastra. Teori Sastra. Yogyakarta: Pustaka Pelajar.

Sarumaha, R., Harefa, D., \& Zagoto, Maria M. (2018). Upaya Meningkatkan Kemampuan Pemahaman Konsep Geometri Transformasi Refleksi Siswa Kelas XII-IPA-B SMA Kampus Telukdalam Melalui Model Pembelajaran Discovery Learning Berbantuan Media Kertas Milimeter. Jurnal Education and development, Vol.6 No.1, 90-96. https://doi.org/10.37081/ed.v6i1.668

Zagoto, Maria M., Yarni, Nevi; Dakhi, O. (2019). Perbedaan Individu dari Gaya Belajarnya Serta Implikasinya Dalam Pembelajaran. Jurnal Review Pendidikan dan Pengajaran, 2(2), 259-265.

Zagoto, Maria M. \& Dakhi, O (2018). Pengembangan Perangkat Pembelajaran Matematika Peminatan Berbasis Pendekatan Saintifik Untuk Siswa Kelas XI Sekolah Menengah Atas. Jurnal Review Pendidikan dan Pengajaran, 1(1), 157-170.

Zagoto, Maria M. (2018). Pengembangan Perangkat Pembelajaran Matematika Berbasis Realistic Mathematic Educations Untuk Siswa Kelas V Sekolah Dasar, Jurnal Education And Development, vol. 3, no. 1, p. 53, Feb. 2018. https://doi.org/10.37081/ed.v3i1.139 